\title{
EVALUASI PROGRAM SISWA ASUH SEBAYA PADA TINGKAT SEKOLAH DASAR DI KECAMATAN BANYUWANGI KABUPATEN BANYUWANGI
}

\author{
WINDA ROSSALIA* \\ SUTOMO \\ ABUL HARIS SURYO NEGORO \\ Program Studi Ilmu Administrasi Negara, Jurusan Ilmu Administrasi \\ Fakultas Ilmu Sosial dan Ilmu Politik \\ Universitas Jember \\ *Email: windarossalia@gmail.com
}

\begin{abstract}
ABSTRAK
Penelitan ini bertujuan mendeskripsikan hasil evaluasi Program Siswa Asuh Sebaya (SAS) pada tingkat sekolah dasar di Kecamatan Banyuwangi Kabupaten Bnayuwangi. Penelitian ini didasari oleh beberapa permasalahan yaitu kurangnya sosialisasi dan koordinasi yang dilakukan oleh Dinas Pendidikan Kabupaten Banyuwangi ke seluruh sekolah di Kabupaten Banyuwangi khususnya pada sekolah dasar di Kecamatan Banyuwangi sehingga menyebabkan munculnya diskresi dan kurangnya pemahaman mengenai program SAS oleh kepala sekolah maupun guru yang menyebabkan pengelolaan SAS pada beberapa sekolah berjalan kurang baik. Untuk mendeskripsikan hasil evaluasi program SAS pada tingkat sekolah dasar di Kecamatan Banyuwangi, peneliti mengacu pada konsep evaluasi Dunn dengan menggunakan enam kriteria evaluasi. Penelitian ini menggunakan pendekatan kualitatif dengan jenis deskriptif. Data yang digunakan berupa data kualitatif dengan jenis data yang terdiri dari data primer dan data sekunder yang dikumpulkan dengan teknik observasi, wawancara dan dokumentasi. Derajat kepercayaan diuji menggunakan teknik triangulasi data. Analisis data menggunakan model interaktif oleh

Miles dan Huberman. Temuan penelitian menunjukkan hasil evaluasi program SAS dapat dilihat dari enam kriteria evaluasi, yaitu efektivitas, efisiensi, kecukupan, pemerataan, responsivitas, dan ketepatan. Hasil penelitian di lapangan menunjukkan bahwa program Siswa Asuh Sebaya telah berjalan secara efektif yang telah membantu siswa miskin dalam meringankan biaya pendidikan meskipun pada beberapa sekolah terdapat kendala dalam pelaksanaannya. Namun berdasarkan hasil pengukuran menggunakan evaluasi kriteria Dunn, program tersebut dapat dilanjutkan pelaksanaannya karena mendapat respon yang baik dari siswa, sekolah, maupun orang tua siswa.
\end{abstract}

Kata Kunci: Evaluasi, Program Pendidikan, Siswa Asuh Sebaya 


\section{PENDAHULUAN}

Jawa Timur memiliki alokasi anggaran pendidikan terkecil kedua dalam APBD setelah Papua. Namun beberapa kabupaten di Jawa Timur memiliki prioritas pembangunan utama dalam bidang pendidikan sehingga APBD mendapat alokasi anggaran tertinggi untuk bidang pendidikan daripada bidang yang lainnya. Salah satu kabupaten yang mengalokasikan anggaran tertinggi untuk pendidikan adalah Kabupaten Banyuwangi. APBD Kabupaten Banyuwangi 2018 mencapai Rp 3 triliun. Pemerintah Kabupaten Banyuwangi memiliki misi untuk mewujudkan aksesbilitas dan kualitas pelayanan bidang pendidikan, kesehatan dan kebutuhan dasar lainnya. Melalui misi tersebut, Pemerintah Kabupaten Banyuwangi mulai membuat kebijakan-kebijakan di sektor pendidikan untuk melakukan perbaikan dengan membuat skala prioritas pembangunan daerah. Salah satu prioritas pembangunan daerah dalam kategori wajib yaitu pendidikan.

Meskipun pendidikan menjadi salah satu prioritas pembangunan, namun terdapat permasalahan di dalamnya. Salah satunya yaitu tingginya persentase penduduk yang berumur 15 tahun ke atas yang ditamatkan pada jenjang SD/MI, menjadi hal yang lebih serius untuk ditangani. Dalam hal ini tangan pemerintah melalui anggaran dalam APBD masih belum bisa menjangkau permasalahan pendidikan di seluruh kecamatan di Kabupaten Banyuwangi. Bantuan dari dana Bantuan Operasional Sekolah (BOS) dan Bantuan Siswa Miskin (BSM) yang berasal dari dana APBN juga belum mampu menjangkau siswa yang miskin seluruhnya dikarenakan pencairan dana yang sering terlambat dan prosedur yang berbelit-belit. Untuk membantu pemerintah dalam membantu penduduk yang belum pernah memperoleh pendidikan maupun yang putus sekolah tanpa mengeluarkan anggaran pendidikan dari APBD maka Pemerintah Kabupaten Banyuwangi membuat suatu program yang dikelola oleh siswa yang dibantu dan didampingi oleh guru dan sumber dana yang 
diperoleh pun dari siswa juga. Program tersebut adalah program Siswa Asuh Sebaya.

Program Siswa Asuh Sebaya yang telah dicanangkan sejak tahun 2011 merupakan salah satu inovasi program dalam meningkatkan pendidikan sebagai upaya dalam menciptakan kondisi agar anak-anak usia sekolah memperoleh peluang untuk bersekolah. Tujuan program Siswa Asuh Sebaya yang tercantum dalam Surat Keputusan Bupati Banyuwangi Nomor 188/182/KEP/429.011/2014 tentang Program Siswa Asuh Sebaya adalah sebagai wujud kepedulian masyarakat yang dilakukan oleh para siswa didik yang mampu secara ekonomi untuk meringankan biaya pendidikan kepada sesama teman satu sekolah yang kurang mampu secara ekonomi.

Pada tahun 2015, Dinas Pendidikan Kabupaten Banyuwangi mengeluarkan Surat Keputusan Kepala Dinas Pendidikan Kabupaten Banyuwangi Nomor: 188/1416/429.101/2015 tentang Standar Operasional Prosedur (SOP) Siswa Asuh Sebaya (SAS) di
Lingkungan Dinas Pendidikan Kabupaten Banyuwangi. Berdasarkan SOP Siswa Asuh Sebaya, pengelolaan program Siswa Asuh Sebaya dilakukan dengan cara membentuk tim SAS yang terdiri atas siswa dan guru pada masingmasing sekolah memiliki tugas untuk mengatur dan mengelola dana yang diperoleh dari hasil sumbangan siswa-siswi. Tim yang dibentuk terdiri dari siswa-siswi pada jenjang kelas tertinggi di sekolah tersebut dan beberapa guru yang ditunjuk langsung oleh kepala sekolah untuk masuk ke dalam tim SAS. Pada jenjang sekolah dasar dan sederajat, guru fokus pada pengumpulan dan pendistribusian dana. Sedangkan pada jenjang SMP dan sederajat, peran guru sebagai motivator untuk mengawasi dan mengarahkan siswa dalam memperoleh dana tersebut. Dana yang dikumpulkan bukan dana dari pemerintah seutuhnya, tetapi diperoleh melalui sumbangan yang diberikan secara sukarela oleh siswa. Dana pemerintah hanya digunakan untuk membantu dalam mempublikasikan program SAS saja. Biasanya orang tua tidak 
memberikan uang secara khusus untuk disumbangkan, tetapi orang tua memberikan uang saku kepada anaknya dengan jumlah yang tetap sehingga anak tersebut dapat mengelola sendiri uangnya digunakan untuk apa. Bantuan yang disalurkan oleh dana SAS berupa barang keperluan yang dibutuhkan oleh siswa kurang mampu dalam segi ekonomi.

Jumlah sekolah dasar yang ada di Kecamatan Banyuwangi yaitu sebanyak 41 sekolah terdiri dari sekolah negeri dan swasta. Dari 41 sekolah tersebut, peneliti memfokuskan penelitian pada tujuh sekolah dasar, yaitu SDN Sobo, SDN 3 Lateng, SDN 2 Tukangkayu, SDN 4 Penganjuran, SDN 1 Lateng, SD Islam Al Khairiyah, dan SD Muhammadiyah. Penentuan tujuh sekolah dasar tersebut didasarkan pada beberapa kriteria, yaitu sekolah yang berada di kota-desa, sekolah negeri-swasta, dan sekolah dengan jumlah siswa besar-kecil. Selain itu penentuan sekolah dasar tersebut juga didasarkan oleh beberapa pertimbangan yang peneliti lakukan selama berada di lapangan yang mendukung untuk pengumpulan data penelitian.

Dalam perkembangannya, pelaksanaan program SAS mengalami beberapa permasalahan seperti kurangnya sosialisasi dan koordinasi yang dilakukan oleh Dinas Pendidikan Kabupaten Banyuwangi kepada seluruh sekolah khususnya pada sekolah dasar di Kecamatan Banyuwangi sehingga memunculkan adanya diskresi dan kurangnya pemahaman mengenai program SAS oleh kepala sekolah maupun guru-guru yang menyebabkan pengelolaan SAS pada beberapa sekolah berjalan kurang baik. Permasalahan lain yang menjadi cerminan dalam kurang maksimalnya pelaksanaan program SAS pada tingkat sekolah dasar di Kecamatan Banyuwangi adalah kurangnya monitoring dan evaluasi yang dilakukan oleh Dinas Pendidikan Kabupaten Banyuwangi. Hal tersebut dibenarkan oleh masingmasing pengelola SAS pada saat peneliti melakukan penggalian data di lapangan. Tidak adanya monitoring dan evaluasi yang dilakukan langsung kepada sekolah- 
sekolah menyebabkan permasalahan yang ada pada pelaksanan program SAS belum bisa dilakukan perbaikan.

Program SAS merupakan suatu program yang dibuat oleh pemerintah Kabupaten Banyuwangi yang dalam pelaksanaannya memerlukan evaluasi untuk melakukan perbaikan. Evaluasi menurut Dunn (Nugroho, 2014: 712) berkenaan dengan informasi mengenai nilai atau manfaat hasil kebijakan. Evaluasi diperlukan untuk melihat kesenjangan antara harapan dengan kenyataan karena tidak semua program kebijakan publik meraih hasil yang diinginkan. Menurut Abidin (2012: 165), pada hakikatnya evaluasi secara lengkap mencakup tiga pengertian. Pertama, evaluasi awal (ex-ante evaluation) yaitu evaluasi yang dilakukan dari proses perumusan kebijakan sampai saat sebelum diimplementasikan.

\section{TINJAUAN PUSTAKA}

\subsection{Efektivitas}

Efektivitas berkenaan dengan apakah suatu alternatif mencapai hasil yang diharapkan, atau mencapai
Kedua, evaluasi dalam proses implementasi (monitoring) diperlukan untuk menunjang keberhasilan implementasi. Ketiga, evaluasi akhir ( ex-post evaluation) yaitu evaluasi yang dilakukan setelah proses implementasi selesai.

Berdasarkan tipe evaluasi yang telah dipaparkan, penulis bermaksud untuk menggunakan evaluasi ketiga yaitu evaluasi akhir untuk melihat sejauh mana tercapainya tujuan program tersebut dalam menyelesaikan permasalahan pendidikan. Oleh karena itu, untuk melihat tercapainya tujuan tersebut dan mengungkapkan hasil yang dapat dinikmati oleh sasaran program, perlu adanya penelitian ini. Sehingga menarik bagi peneliti untuk melakukan penelitian lebih lanjut terkait evaluasi hasil program SAS pada tingkat sekolah dasar di Kecamatan Banyuwangi Kabupaten Banyuwangi.

tujuan dari diadakannya tindakan. Dalam evaluasi yang dilakukan efektivitas digunakan untuk melihat sejauh mana realisasi tujuan dari 
program Siswa Asuh Sebaya yang ada pada sekolah dasar di Kecamatan Banyuwangi. Adapun indikator yang dapat digunakan dalam melihat efektivitas program Siswa Asuh Sebaya pada sekolah dasar di Kecamatan Banyuwangi yaitu dengan melihat prosedur pelaksanaan pengelolaan program Siswa Asuh Sebaya yang meliputi pembentukan tim SAS, pengumpulan dan pemberian dana SAS, serta penyampaian laporan dana SAS.

\subsection{Efisiensi}

Kriteria ini berkaitan dengan jumlah usaha yang diperlukan untuk menghasilkan tingkat efektivitas dan usaha yang biasanya ditentukan melalui perhitungan biaya per unit produk atau layanan. Untuk melihat tingkat efisiensi program Siswa Asuh Sebaya pada sekolah dasar di Kecamatan Banyuwangi, peneliti telah melakukan wawancara dan penggalian data di lapangan.

\subsection{Kecukupan}

Kriteria ini berhubungan dengan pertanyaan seberapa jauh suatu tingkat efektifitas memuaskan kebutuhan, nilai, atau kesempatan para pihak yang terlibat dalam memecahkan suatu masalah. Kecukupan masih berhubungan dengan efektifitas dengan mengukur atau memprediksi seberapa jauh alternatif yang ada dapat memuaskan kebutuhan, nilai, atau kesempatan dalam menyelesaikan masalah yang terjadi. Kecukupan dalam program ini artinya kesesuaian antara desain program dengan hasil atau tujuan yang diinginkan. Dalam program ini tujuan utamanya adalah meringankan beban biaya pendidikan siswa yang kurang mampu secara ekonomi dalam satu sekolah. Untuk kriteria kecukupan ini, dapat dilihat dari ketersediaan alokasi dana SAS terhadap kebutuhan personal siswa yang kurang mampu secara ekonomi.

\subsection{Pemerataan}

Pemerataan dalam kebijakan publik dapat dikatakan mempunyai arti dengan keadilan yang diberikan dan diperoleh sasaran kebijakan publik. Kriteria Pemerataan erat berhubungan dengan rasionalitas legal dan sosial serta menunjuk pada distribusi akibat dan usaha 
kelompok-kelompok yang berbeda dalam masyarakat. Kebijakan yang berorientasi pada pemerataan adalah kebijakan yang akibatnya atau usahanya secara adil didistribusikan. Untuk kriteria ini dapat dilihat dari tingkat kesempatan siswa-siswi yang tidak mampu secara ekonomi dalam mendapatkan bantuan pembiayaan pendidikan.

\subsection{Responsivitas}

Responsivitas dalam kebijakan publik dapat diartikan sebagai respon dari suatu aktifitas yang berarti tanggapan sasaran kebijakan publik atas penerapan suatu kebijakan. Responsivitas berkaitan dengan seberapa kebijakan dapat memuaskan kebutuhan, preferensi, atau nilai kelompok-kelompok masyarakat tertentu. Keberhasilan kebijakan dapat dilihat dari tanggapan masyarakat yang menanggapi pelaksanaan setelah terlebih dahulu memprediksi pengaruh yang akan terjadi jika kebijakan akan dilaksanakan, juga tanggapan masyarakat setelah kebijakan sudah mulai dapat dirasakan dalam bentuk dukungan atau berupa penolakan. Artinya apakah program tersebut benar-benar menjangkau kelompok sasaran atau memang selain kelompok sasaran merupakan objek responsivitas. Kriteria ini dapat dilihat dari tingkat kepuasan siswa maupun orang tua siswa.

\subsection{Ketepatan}

Ketepatan merujuk pada nilai atau harga dari tujuan program dan pada kuatnya asumsi yang melandasi tujuan-tujuan tersebut. Kriteria yang dipakai untuk menseleksi sejumlah alternatif untuk dijadikan rekomendasi dengan menilai apakah hasil dari alternatif yang direkomendasikan tersebut merupakan pilihan tujuan yang layak. Kriteria ketepatan dihubungkan dengan rasionalitas substantif karena kriteria ini menyangkut substansi tujuan bukan cara atau instrumen untuk merealisasikan tujuan tersebut. 


\section{METODE PENELITIAN}

Penelitian ini merupakan jenis penelitian deskriptif yang menggunakan pendekatan kualitatif. Lokasi penelitian yaitu di Kecamatan Banyuwangi

Kabupaten

Banyuwangi. Waktu penelitian pada bulan Februari hingga bulan Mei 2018. Sumber data didapatkan melalui data primer dan data sekunder melalui metode pengumpulan data yaitu observasi, wawancara dan dokumentasi sedangkan alat untuk mengumpulkan data berupa alat perekam, draf wawancara dan buku catatan. Teknik penentuan informan dilakukan secara purposive yakni pemilihan informan dengan mekanisme disengaja terhadap narasumber yang telah memenuhi kriteria yang telah ditetapkan peneliti dan dianggap paling mengetahui tentang masalah yang diteliti untuk dijadikan sebagai sumber informasi. Teknik menguji keabsahan data menggunakan triangulasi data. Teknik analisis data mengacu pada pendapat Miles dan Huberman (Sugiyono, 2017: 241) yaitu pengumpulan data, reduksi data, penyajian data serta kesimpulan.

\section{HASIL PENELITIAN DAN PEMBAHASAN}

\section{Efektivitas}

Pada pembentukan tim SAS oleh masing-masing sekolah dasar di Kecamatan Banyuwangi dari penggalian data di lapangan dan hasil wawancara dapat disebutkan bahwa terdapat 4 sekolah yang telah membentuk tim SAS dari 7 sekolah dasar yang telah peneliti wawancarai, yaitu SDN 4 Penganjuran, SDN 1 Lateng, SDN 2 Tukangkayu, dan SD Islam Al Khairiyah. Terbentuknya tim SAS pada masing-masing sekolah dasar bisa dilihat letak perbedaannya antara sekolah dasar yang satu dengan sekolah dasar yang lain. Sekolah dasar dengan jumlah siswa yang sedikit yaitu di bawah 150 siswa, program SAS hanya dikelola oleh guru yang ditunjuk langsung oleh kepala sekolah dasar tersebut tanpa melibatkan siswa dalam pengelolaan. Sedangkan sekolah dasar dengan jumlah siswa 
di atas 150 siswa, telah membentuk tim SAS guru bersama siswa dengan kepala sekolah sebagai penanggung jawab yang telah dibuat struktur organisasi tim SAS. Salah satu sekolah seperti SDN 1 Lateng membuat struktur tim SAS untuk masing-masing tim SAS siswa dan pembina tim SAS sendiri. Sedangkan di sekolah lain struktur tim SAS digabung antara siswa dan guru pembina. Namun jika dilihat dari hasil penggalian data di lapangan dengan prosedur yang telah tercantum di dalam SOP, pembentukan tim SAS pada masingmasing sekolah dasar sudah dilaksanakan cukup baik. Hal tersebut dikarenakan memang kondisi sekolah dasar di Kecamatan Banyuwangi berbeda- beda, sehingga terdapat beberapa sekolah yang tidak bisa membentuk tim SAS.

Pada tahap pengumpulan dana SAS, berdasarkan penggalian data dan hasil wawancara yang peneliti lakukan bahwa tidak adanya aturan yang rinci terkait waktu dan jumlah dana yang harus dikumpulkan oleh masing-masing sekolah sehingga tiap sekolah memiliki perbedaan dalam metode dan waktu pengumpulan dana SAS. SDN Sobo menjadikan guru sebagai motivasi siswa dalam mengumpulkan dana SAS dengan menggunakan kotak dana SAS pada saat kegiatan bersama pada hari Jumat. Pada SDN 3 Lateng, tidak diberikan motivasi apapun hanya berjalan begitu saja yang dilakukan pada saat hari Jumat setelah melakukan doa bersama yang dikumpulkan menggunakan kotak dana SAS. SDN 2 Tukangkayu memotivasi siswa dengan cara memberikan petuah atau kata-kata mutiara yaitu "tangan di atas lebih baik daripada tangan di bawah". Metode pengumpulan SAS dilakukan dengan cara masing-masing kelas mengumpulkan dana SAS kepada bendahara kelas kemudian bendahara kelas menyerahkan hasil dana SAS yang dikumpulkan kepada ketua tim SAS dengan maksimal penyerahan dana SAS dilakukan pada hari Jumat saat pulang sekolah. Berbeda pula dengan SDN 4 Penganjuran, pengumpulan dana SAS dilakukan pada hari Senin dengan mengumpulkan dana SAS pada masing-masing kelas yang 
dikumpulkan kepada koordinator kelas kemudian pengelola SAS yang berasal dari siswa kelas 5 dan 6 akan mendatangi setiap kelas untuk mengambil hasil dana SAS yang akan dikumpulkan. Begitu pula dengan SDN 1 Lateng, tim SAS memotivasi siswa dengan mengadakan suatu perlombaan perolehan dana SAS tertinggi pada setiap kelas yang mengumpulkan yang akan diumumkan setiap hari Senin saat upacara bendera. Pengumpulan dana SAS dilakukan dengan cara masing-masing kelas mengumpulkan dana SAS kepada pengurus kelas yang didampingi oleh wali kelasnya. Kemudian pengelola SAS yang berasal dari kelas 6 akan mengambil dana SAS yang telah dikumpulkan kepada pengurus kelas dan juga wali kelas yang kemudian melakukan penghitungan perolehan dana SAS pada masing-masing kelas untuk menentukan kelas dengan perolehan tertinggi.

Berdasarkan penggalian data di lapangan dan hasil wawancara dapat disebutkan bahwa penentuan siswa yang akan menerima bantuan dari program SAS dan waktu pemberian dana SAS kepada siswa yang diasuh pada masing-masing sekolah dasar memiliki cara yang berbeda-beda, meskipun dapat dilihat juga terdapat kesamaan pada beberapa sekolah dasar. Jika menelaah secara tersirat, setiap sekolah dasar tidak melibatkan kepala sekolah selaku penanggung jawab pelaksanaan SAS di setiap sekolah. Padahal kepala sekolah memiliki tugas dalam melakukan penilaian terhadap siswa yang tidak mampu. Hal tersebut dijelaskan pada Keputusan Bupati Banyuwangi Nomor 188/182/KEP/429.011/2014 tentang Program Siswa Asuh Sebaya Bagian Keempat mengenai bantuan SAS.

Namun dalam pelaksanaannya pada tahap penentuan siswa yang akan dibantu, kepala sekolah tidak dilibatkan dalam pengambilan keputusan. Berdasarkan wawancara yang peneliti lakukan, hampir semua sekolah yang peneliti wawancarai mengatakan jika kepala sekolah sudah memberikan kewenangan kepada tim SAS dalam melakukan penilaian ketidakmampuan siswa. Tidak dipungkiri pula apabila kepala sekolah juga memberi tahu jika ada 
anak yang membutuhkan bantuan dari program SAS.

Pelaporan dana SAS pada tahap ini dilakukan setiap bulan oleh masing-masing sekolah dasar. Laporan secara tertulis akan diberikan kepada UPT Pendidikan Kecamatan Banyuwangi, sedangkan laporan secara online akan diupload melalui website Dinas Pendidikan Kabupaten Banyuwangi yaitu pendidikan.banyuwangikab.go.id.

Pada tahap ini, masing-masing sekolah dasar hanya melaporkan mengenai data pemasukan dana SAS yang diperoleh selama sebulan saja dan jumlah siswa yang dibantu, namun tidak disertai dengan data penyaluran dana SAS yang digunakan untuk apa saja. Laporan yang dikirimkan kepada dinas terkait tersebut sesuai dengan pemasukan jumlah dana SAS yang diperoleh pada saat bulan tersebut. Hanya saja apabila melihat langsung di website miliki Dinas Pendidikan Kabupaten Banyuwangi, peneliti melihat ada yang sesuai dengan jumlah yang diperoleh oleh sekolah dasar tersebut namun juga ada yang tidak sesuai. Hal tersebut dikarenakan laporan tersebut digabung dengan laporan Badan Amil Zakat (BAZ). Untuk pelaporan pada tingkat sekolah dasar secara online, bisa dilakukan sendiri melalui operator sekolah maupun bisa dilakukan juga oleh UPT Pendidikan Kecamatan Banyuwangi. Dokumentasi terkait pelaporan dana SAS secara online ini tidak semua sekolah dasar memilikinya.

Dalam penelitian ini, hasil yang diinginkan oleh masing-masing sekolah dasar dapat dikatakan telah berhasil. Meskipun tiap sekolah memiliki perbedaan dalam proses pengelolaan, namun hal itu tidak menjadi kendala bagi tiap-tiap sekolah untuk mencapai hasil yang diinginkan tersebut. Sehingga dalam hal ini program SAS dapat meringankan beban biaya pendidikan siswa yang kurang mampu secara ekonomi. Sesuai dengan tujuan program SAS yang tercantum dalam SK Bupati Banyuwangi Nomor 24 Tahun 2017 tentang Program Siswa Asuh Sebaya menyatakan bahwa tujuan program tersebut adalah untuk membantu meringankan beban pembiayaan pendidikan siswa yang kurang mampu secara ekonomi yang 
diberikan dengan sumbangan yang diberikan seikhlasnya dari siswa yang mampu secara ekonomi. Untuk itu, dapat dikatakan bahwa program ini berjalan secara efektif karena telah mencapai hasil yang diinginkan sesuai dengan tujuan program SAS tersebut.

\section{Efisiensi}

Hasil dari kutipan wawancara dan penggalian data di lapangan yang telah dipaparkan di atas dapat disimpulkan bahwa dengan adanya program Siswa Asuh Sebaya, siswa yang kurang mampu secara ekonomi perlahan-lahan dapat memenuhi kebutuhan sekolahnya. Meskipun tiap sekolah memiliki kebijakan masing-masing dalam menjalankan program tersebut, namun manfaatnya sangat dirasakan oleh terutama oleh siswa yang menerima bantuan tersebut. Hanya dengan bermodal sumbangan seikhlasnya yang diberikan oleh siswa yang ingin menyumbang dengan menyisihkan uang saku senilai Rp500,00, Rp1.000,00 maupun yang lebih banyak lagi nominal uang yang disumbangkan ternyata dapat membantu siswa yang benar- benar membutuhkan untuk membeli kebutuhan sekolahnya seperti seragam, sepatu, tas, dan alat-alat perlengkapan sekolah lainnya.

\section{Kecukupan}

Hasil wawancara dan pengumpulan data yang dilakukan di lapangan, terdapat beberapa sekolah yang memiliki jumlah pengumpulan dana yang besar. Sekolah dasar tersebut yaitu SDN Sobo, SDN 2 Tukangkayu, SDN 4 Penganjuran, SDN 1 Lateng, SD Islam Al Khairiyah dan SD Muhammadiyah. Dengan jumlah dana SAS yang dikumpulkan tersebut mampu diberikan dan mencukupi kebutuhan pendidikan siswa yang kurang mampu secara ekonomi seperti biaya SPP, perlengkapan belajar (buku, pulpen, penghapus, dan lain-lain), tas, dan lain sebagainya. Namun SDN 3 Lateng masih belum mampu mencukupi kebutuhan personal pendidikan siswa yang kurang mampu secara ekonomi. Hal tersebut dikarenakan jumlah dana yang dikumpulkan oleh SDN 3 Lateng berdasarkan data yang peneliti 
temukan di lapangan menyatakan bahwa selama beberapa bulan pada tahun pelajaran 2016/2017 tidak memiliki pemasukan dana SAS. Padahal siswa yang harus dibantu berjumlah 28 siswa. Tidak adanya pemasukan membuat siswa yang kurang mampu tidak mendapat bantuan.

Berdasarkan penjelasan dalam kutipan wawancara kepada sekolah dasar, dapat disimpulkan bahwa hampir semua sekolah yang peneliti lakukan penggalian data di lapangan, dengan adanya dana SAS yang diberikan untuk membantu siswa yang kurang mampu secara ekonomi, siswa yang dibantu merasa sangat terbantu karena telah meringankan beban biaya pendidikannya. Hal ini berarti meskipun tiap sekolah memiliki perbedaan dalam pengelolaan dana SAS, namun hal tersebut tidak menyurutkan niat pihak sekolah yang dibantu dengan siswa-siswa yang juga memberikan sumbangan kepada siswa yang dibantu agar dapat menyelesaikan masalahnya terutama masalah pembiayaan pendidikan baik berupa barang maupun dalam bentuk uang.
Hasil dari evaluasi ini menyatakan bahwa dana SAS yang diberikan untuk membantu siswa memberikan hasil yang efektif dengan mampu menyelesaikan masalah yang terjadi pada masing-masing personal siswa.

\section{Pemerataan}

Hasil wawancara dan pengumpulan data di lapangan menunjukkan bahwa pemberian bantuan dana SAS sudah dilakukan dengan memberikannya pada siswa yang kurang mampu secara ekonomi yang diberikan secara merata, baik berupa jumlah maupun diberikan sesuai dengan kebutuhan siswa tersebut. Artinys terdapat beberapa sekolah yang memberikan jumlah dana SAS yang sama kepada siswa yang miskin, yaitu SDN 2 Tukangkayu dan SD Muhammadiyah. Sedangkan sekolah dasar lainnya seperti SDN Sobo, SDN 4 Penganjuran, dan SDN 1 Lateng memberikan bantuan sesuai dengan kebutuhan siswa, baik berupa uang tunai maupun dalam bentuk barang. Sedangkan SDN 3 Lateng dan SD Islam Al Khairiyah belum memberikan dananya secara merata 
dikarenakan kondisi pemasukan dana yang sangat minim di SDN 3 Lateng sedangkan di SD Islam Al Khairiyah tidak ditemukan data pendistribusian dana karena pengelola SAS tidak mengarsipkan dengan baik datadatanya.

Berdasarkan penjelasan yang telah dipaparkan oleh informan pada hasil wawancara dan juga dari penggalian data di lapangan dapat disimpulkan bahwa program Siswa Asuh Sebaya pada tingkat sekolah dasar di Kecamatan Banyuwangi telah diberikan secara merata kepada siswa yang membutuhkan bantuan. Masing-masing sekolah dasar memiliki caranya tersendiri dalam menentukan siswa yang akan menerima bantuan dari program SAS sehingga pendistribusian bantuan tersebut bisa dirasakan oleh siswa yang kurang mampu secara ekonomi.

\section{Responsivitas}

Hasil penelitian menunjukkan bahwa tingkat kepuasan siswa maupun orang tua siswa merasa puas dengan adanya program SAS ini. Menurut mereka bantuan yang diberikan SAS sangat membantu siswa yang berasal dari keluarga dengan tingkat ekonomi menengah ke bawah karena dapat meringankan biaya pendidikan anak-anaknya sehingga mereka mampu menyekolahkan anak-anaknya tanpa harus mengeluarkan biaya pendidikan yang cukup banyak. Selain itu, dari siswa yang mampu secara ekonomi juga memiliki kepuasan terhadap program SAS ini karena dengan adanya program ini mereka mampun meningkatkan kesadaran dan kepedulian terhadap teman-teman sebayanya yang kurang mampu yang harus dibantu.

Berdasarkan hasil wawancara dan penggalian data di lapangan, peneliti dapat menyimpulkan bahwa program SAS yang dilaksanakan oleh masing-masing sekolah dasar memberikan respon yang baik dan positif karena bantuan yang diberikan memberikan semangat bagi siswa yang terbantu untuk tidak menjadikan alasan biaya pendidikan untuk tidak bersekolah.

\section{Ketepatan}

Hasil wawancara dan penggalian data di lapangan yang telah peneliti 
lakukan, dapat disimpulkan bahwa program SAS ini sangat layak dan berguna bagi siswa yang kurang mampu secara ekonomi. Tidak hanya itu pihak-pihak yang terlibat secara langsung maupun tidak juga

\section{KESIMPULAN DAN SARAN}

Berdasarkan hasil penelitian dan analisis atas data yang terkumpul dapat disimpulkan bahwa dari kriteria pengukuran menurut Dunn, permasalahan siswa dalam membiayai pendidikan terutama kebutuhan pendidikannya seperti tas, sepatu, alat tulis, dan sebagainya bisa tercukupi. Masing-masing sekolah dasar telah memberikan bantuan secara merata, artinya siswa dibantu sesuai dengan kebutuhannya. Pelaksanaan program SAS mendapat respon yang baik dan positif dari siswa, sekolah maupun orang tua siswa. Penerima program SAS merasa sangat terbantu karena siswa menjadi lebih semangat dalam belajar dan bersekolah serta mampu meringankan beban orang tua. Dengan kata lain, pelaksanaan program Siswa Asuh Sebaya pada tingkat sekolah dasar di Kecamatan merasakan hal yang sama karena memberikan pengaruh juga pada dirinya yang bisa mambantu siswa yang membutuhkan meskipun dengan sumbangan seikhlasnya.

Banyuwangi sudah efektif. Meskipun ada beberapa sekolah yang mengalami kendala dalam proses pelaksanannya, namun respon dari target group maupun non target group terhadap bantuan dana SAS tersebut sangatlah baik, sehingga siswa yang menerima bantuan tersebut lebih semangat lagi untuk belajar dan bersekolah.

Kelancaran pelaksanaan program SAS perlu diwujudkan, oleh karena itu terdapat beberapa saran yang dapat digunakan sebagai acuan yakni SOP yang telah dibuat perlu adanya pembaruan setiap satu tahun sekali. Hal tersebut dilakukan agar program SAS dapat dilaksanakan dan dikembangan sesuai dengan perkembangan zaman, Dinas Pendidikan Kabupaten Banyuwangi perlu melakukan koordinasi dan evaluasi setiap satu bulan sekali 
untuk mengetahui permasalahan atau kekurangan-kekurangan yang terjadi dalam pelaksanaan program SAS pada sekolah dasar sehingga permasalahan mengenai pemahaman maupun teknis pelaksanaan program dapat diselesaikan, semua sekolah perlu melibatkan siswa dalam pengelolaan SAS dengan membuat tim SAS agar kemampuan siswa

\section{DAFTAR PUSTAKA}

Buku

Abidin, Said Zainal. 2012. Kebijakan Publik. Jakarta: Salemba Humanika.

Bungin, Burhan. 2015. Metodologi Penelitian Sosial dan Ekonomi: Format-Format Kuantitatif dan Kualitatif untuk Studi Sosiologi, Kebijakan Publik, Komunikasi, Manajemen, dan Pemasaran. Jakarta: Prenadamedia Group.

Dunn, William N. 2003. Pengantar Analisis Kebijakan Publik. Yogyakarta: Gajah Mada University Press.

Hasbullah. 2016. Kebijakan Pendidikan: Dalam Perspektif Teori, Aplikasi, dan Kondisi Objektif Pendidikan di Indonesia. Jakarta: PT Raja Grafindo Persada.

Nugroho, Riant. 2014. Public Policy. Jakarta: PT Elex Media Komputindo. dalam bekerja tim dapat diasah dan belajar untuk bertanggung jawab, serta pengelola program Siswa Asuh Sebaya sebaiknya melakukan pembaruan tiap tahunnya agar pelaksanaan program tersebut pada masing-masing sekolah dapat berkembang sehingga siswa tidak merasa bosan jika pelaksanaannya secara monoton tiap tahunnya.

Subarsono. 2015. Analisis Kebijakan Publik: Konsep, Teori dan Aplikasi. Yogyakarta: Pustaka Pelajar.

Sugiyono. 2017. Metode Penelitian Kebijakan. Bandung: PT Alfabeta.

Suharsono. 2013. Dasar-Dasar Kebijakan Publik: Kajian Proses dan Analisis Kebijakan. Yogyakarta: Ombak.

Syafaruddin. 2008. Efektivitas Kebijakan Pendidikan: Konsep, Strategi, dan Aplikasi Kebijakan Menuju Organisasi Sekolah Efektif. Jakarta: PT Rineka Cipta.

Dasar Hukum

Undang-Undang Nomor 20 Tahun 2003 tentang Sistem Pendidikan Nasional

Keputusan Bupati Banyuwangi Nomor 188/182/KEP/429.011/2014 tentang Program Siswa Asuh Sebaya 
Surat Keputusan Kepala Dinas Pendidikan Kabupaten

Banyuwangi Nomor 188/1416/429.101/2015 tentang Standar Operasional Prosedur (SOP) Siswa Asuh Sebaya (SAS) di Lingkungan Dinas Pendidikan Kabupaten Banyuwangi

\section{Lembaga}

Badan Pusat Statistik Kabupaten Banyuwangi. 2017. Kecamatan Banyuwangi Dalam Angka 2017. Banyuwangi: BPS Kabupaten Banyuwangi

Universitas Jember. 2016. Pedoman Penulisan Karya Ilmiah. Jember: Jember University Press.

\section{Internet}

http://www.banyuwangi.go.id/ (diakses pada tanggal 25 Maret 2018)

http://www.banyuwangikab.go.id/ (diakses pada tanggal 25 Maret 2018)

http://jendela.data.kemdikbud.go.id/j endela/index.php/chome/dashb oard// (diakses pada tanggal 13 April 2018)

http://www.republika.co.id/berita/pe ndidikan/berita/10/12/25/15429 8-80-persen-anak-indonesiaputus-sekolah-karena-ekonomi (diakses pada tanggal 19 November 2017)

http://student.cnnindonesia.com/eduk asi/20170417145047-445208082/tingginya-angka-putussekolah-di-indonesia/ (diakses pada tanggal 19 November 2017) 